\title{
Penerapan Metode Irigasi Tetes Guna Mendukung Efisiensi Penggunaan Air di Lahan Kering
}

Steven Witman ${ }^{1 *}$

${ }^{1}$ Balai Pengkajian Teknologi Pertanian Papua Barat

\section{ARTIKEL INFO}

Sejarah artikel

Diterima 10/03/2021

Diterima dalam bentuk revisi 23/03/2021

Diterima dan disetujui 30/03/2021

Tersedia online 22/06/2021

Kata kunci

Drip irrigation

Efisiensi

Kebutuhan air

\begin{abstract}
ABSTRAK
Tingkat efisiensi dari penggunaan air yang ada dilahan pertanian bahwasanya dapat dioptimalkan dengan cara melakukan penggunaan metode teknik irigasi yang tepat dikarenakan teknologi irigasi merupakan salah satu komponen yang dirasa penting karena tingkat produksi dari hasil pertanian ditentukan berdasarkan kondisi tanah, perawatan terhadap tanaman, kecukupan air pada tanaman serta iklim yang ada. Dalam bidang pertanian faktor iklim adalah sesuatu hal yang tidak dapat dihindari terutama kondisi iklim saat musim kemarau, tentu bisa menjadi suatu kendala terhadap pertumbuhan tanaman, dikarenakan pasokan air terhadap tanaman kurang terpenuhi, dengan penerapan metode Irigasi tetes bisa menjadi salah satu solusi dalam menangani permasalahan kebutuhan air pada tanaman. Metode penerapan irigasi tetes ini yakni pemberian air dalam volume kecil dan berkelanjutan, irigasi tetes ini juga bertujuan untuk menjaga kelembaban tanah dan kehilangan air yang disebabkan musim kemarau sehingga ketersediaan air bagi tanaman terpenuhi. Teknik irigasi tetes inilah yang diharapkan dapat membantu dalam pemenuhan kebutuhan air dan tanaman sehingga dapat meningkatnya pemanfaaatan unsur hara pada tanah, mempercepat bibit tanaman untuk beradaptasi, dan juga nantinya akan meningkatnya keberhasilan tanaman tersebut untuk bisa tumbuh. Untuk memaksimalkan tingkat efisiensi dalam penggunaan air bisa menggunakan tanah yang memiliki tekstur liat dikarenakan tekstur tanah seperti ini memiliki tingkat penyimpanan air yang sangat tinggi. Selain itu pengaplikasian sistem irigasi ini bisa dilakukan pada tanaman buah ataupun sayuran.
\end{abstract}

(C) 2021 Politeknik Pembangunan Pertanian Manokwari 


\section{ABSTRACT}

The level of efficiency of the use of existing water in agricultural land can be optimized by using the right irrigation technique method because irrigation technology is one of the components that are considered important. After all, the level of production of agricultural products is determined based on soil conditions, plant care, adequacy of water in plants. as well as the existing climate. In agriculture, the climate factor is something that cannot be avoided, especially climatic conditions during the dry season, of course, it can be an obstacle to plant growth, because the water supply to plants is not fulfilled, with the application of drip irrigation method can be one solution in dealing with the problem of needs. water in plants. The method of applying drip irrigation is the provision of water in small and sustainable volumes, this drip irrigation also aims to maintain soil moisture and water loss caused by the dry season so that water availability for plants is fulfilled. This drip irrigation technique is expected to help meet the needs of water and plants so that it can increase the use of nutrients in the soil, accelerate plant seeds to adapt, and also increase the success of these plants to grow. To maximize the level of efficiency in water use, you can use soil that has a clay texture because this soil texture has a very high water retention rate. In addition, the application of this irrigation system can be done on fruit or vegetable crops the level of

\section{PENDAHULUAN}

Masalah kekurangan air di beberapa daerah bukanlah hal yang tidak mungkin, khususnya di beberapa daerah terutama daerah yang memiliki curah hujan yang sedikit. Sedangkan di bidang pertanian, air memiliki peranan penting karena air merupakan salah satu kebutuhan utama yang wajib harus dipenuhi oleh tanaman.

Sistem pertanian tadah hujan rentan terhadap dampak perubahan iklim. Namun, dampak tersebut juga tergantung tingkatan produksi pertanian. Dampak dari perubahan efficiency of the use of existing water in agricultural land can be optimized by using the right irrigation technique method because irrigation technology is one of the components that are considered important because the level of production of agricultural products is determined based on soil conditions, plant care, adequacy of water in plants. as well as the existing climate. In agriculture, the climate factor is something that cannot be avoided, especially climatic conditions during the dry season, of course, it can be an obstacle to plant growth, because the water supply to plants is not fulfilled, with the application of the drip irrigation method it can be one solution in dealing with the problem of needs. water in plants. The method of applying drip irrigation is the provision of water in small and sustainable volumes, this drip irrigation also aims to maintain soil moisture and water loss caused by the dry season so that water availability for plants is fulfilled. This drip irrigation technique is expected to help meet the needs of water and plants so that it can increase the use of nutrients in the soil, accelerate plant seeds to adapt, and also increase the success of these plants to grow. To maximize the level of efficiency in water use, you can use soil that has a clay texture because this soil texture has a very high water retention rate. In addition, the application of this irrigation system can be done on fruit or vegetable crop stems that are italicized.

iklim dan variabilitas pada produksi pertanian akan menimbulkan kebijakan dan praktek yang tepat terhadap sistem produksi pertanian yang berkelanjutan (Olayide et al.,2016)

Pemberian air untuk memenuhi kebutuhan air pada tanaman melalui pengairan lahan biasa disebut dengan irigasi. Pemberian air dengan sistem irigasi tertentu identik dengan jenis dan kebutuhan air pada setiap tanaman. Salah satu teknologi irigasi hemat air adalah sistem irigasi sprinkler atau curah dan irigasi tetes. Karakter dari irigasi curah yang menyebarkan air berupa butiran-butiran kecil 
yang menjadikan sistem irigasi ini dapat diterapkan pada tanaman sayur maupun palawija karena efisiensinya yang cukup tinggi untuk memenuhi kebutuhan air pada suatu tanaman. Air sebagai substansi pelarut dan hara tanaman berperan menentukan kesuburan tanah sebagaimana mikrobiologi yang ada dalam tanah berperan sebagai agen aktivator kesuburan tanah (Kurniati, 2014).

Pada saat musim kemarau, terutama pada masa vegetatif (masa tumbuhnya akar dan cabang), penyiraman harus dilakukan 3-4 hari sekali untuk menjaga ketersediaan air. Kekurangan air pada masa vegetatif dapat menyebabkan tanaman layu dan malas bertunas. Oleh karena itu, untuk memperoleh pertumbuhan tanaman yang optimal, penyiraman harus dilakukan secara teratur agar kebutuhan air dapat terpenuhi sepanjang siklus hidup tanaman, terutama pada musim kemarau (Rana et al., 2014)

Irigasi adalah istilah yang berkaitan dengan penyaluran air dari sumber ke tanaman. Sistem irigasi yang banyak digunakan adalah irigasi curah di permukaan tanah. Irigasi ini membutuhkan air dalam jumlah banyak sedangkan tingkat efisiensi penggunaan airnya rendah. Untuk mengatasi keterbatasan air, sistem irigasi tetes merupakan pilihan tepat dalam meningkatkan efisiensi penggunaan air. Menurut Hadiutomo (2012), irigasi tetes adalah metode pemberian air pada tanaman secara langsung, baik pada areal perakaran tanaman maupun pada permukaan tanah melalui tetesan secara kontinu dan perlahan. Penerapan teknologi irigasi tetes atau sering disebut Trickle Irrigation adalah irigasi yang menggunakan jaringan aliran dengan memanfaatkan gaya gravitasi. Jaringan irigasi tetes terdiri dari pipa utama, pipa sub utama dan pipa lateral (Ilyas, 2013).

Irigasi tetes dapat dibedakan menjadi 3 macam yang berdasarkan jenis cucuran airnya, yaitu (a) Air merembes sepanjang pipa lateral (viaflow), (b) Air menetes atau memancar melalui alat aplikasi yang dipasang pada pipa lateral, dan (c) Air menetes atau memancar melalui lubang-lubang pada pipa lateral (Prastowo, 2010)

Irigasi tetes (Drip Irrigation) merupakan salah satu teknologi mutakhir dalam bidang irigasi yang telah berkembang di hampir seluruh dunia. Teknologi ini pertama diperkenalkan di Israel, dan kemudian menyebar hampir ke seluruh pelosok penjuru dunia. Pada hakikatnya teknologi ini sangat cocok diterapkan pada kondisi lahan berpasir, air yang sangat terbatas, iklim yang kering dan komoditas yang diusahakan mempunyai ekonomis yang tinggi (Pasaribu et al., 2013). Selain itu menurut Umar et al. (2011) Keuntungan dari penerapan irigasi tetes dapat mengurangi bahaya salinitas pada tanaman karena akumulasi garam disekitar perakaran dapat dicuci (leaching) secara efektif.

Salah satu sistem irigasi yang dapat diterapkan pada wilayah yang memiliki keterbatasan air adalah irigasi tetes. Irigasi tetes merupakan salah satu metode pemberian air dengan cara meneteskan air melalui pipa-pipa di sekitar tanaman atau sepanjang larikan tanaman (Marpaung, 2013). Pada sistem irigasi tetes, hanya sebagian dari daerah perakaran yang terbasahi tetapi seluruh air yang diberikan 
dapat diserap dengan cepat pada kondisi kelembaban tanah rendah (Ekaputra et al., 2016)

Teknik pengairan dengan irigasi tetes adalah pemberian air yang dilakukan secara terbatas dengan menggunakan suatu wadah/tempat yang dipergunakan sebagai alat penampung air sementara yang disertai lubang tetes di bawahnya. Air akan ke luar secara perlahan-lahan dalam bentuk suatu tetesan ketanah yang secara perlahan nantinya akan membasahi tanah. Lubang tetes inilah yang nantinya akan diatur dengan cara sedemikian rupa sehingga nantinya air tersebut cukup untuk membasahi tanah di sekitar tempat tanaman itu hidup. Pada prinsipnya pemberian air dengan cara menggunakan irigasi tetes diperlukan sebagai efisiensi penggunaan air sehingga dapat mengurangi kehilangan air yang dirasa cepat akibat penguapan karena suhu yang tinggi. Menurut (Haryati et al., 2011) Efisiensi penggunaan air di lahan pertanian dapat dioptimalkan melalui penggunaan teknik irigasi yang tepat, selain itu, irigasi tetes mampu mempertahankan kondisi air tanah pada zona perakaran tanaman pada kisaran kapasitas lapang dan titik layupermanen (Afriyana et al., 2012).

Metode pengairan dengan irigasi tetes bisa menjadi suatu pilihan yang dapat diterapkan di lahan yang memiliki ketersediaan air yang sangatlah terbatas serta kondisi fisik dari lahan yang kurang mendukung, karena dengan metode irigasi tetes air langsung diserap oleh akar tanaman dan tidak akan mengalami fase penguapan secara berlebih

\section{HASIL DAN PEMBAHASAN}

Saat ini jumlah penduduk mulai meningkat, oleh karena itu kebutuhan khususnya air juga akan meningkat. Sedangkan untuk ketersediaan sumber air mulai berkurang, hal ini juga disebabkan juga oleh penebangan hutan yang dilakukan secara berlebihan dan juga penebangan yang dilakukan dengan tidak bertanggung jawab. Pada daerah yang rawan akan kekeringan yang hanya mengandalkan air hujan sebagai sumber pengairan, hal inilah yang akan menjadi masalah utama bagi kehidupan masyarakat terutama yang berada di dalam sektor pertanian

Lahan kering pada dasarnya merupakan lahan-lahan yang secara alamiahnya memiliki beberapa kendala sehingga dalam upaya pemanfaatannya untuk dijadikan lahan budidaya yang produktif untuk pembudidayaan tanaman butuh upaya yang ekstra. Kendala yang umum terjadi yakni kesulitan dalam menyediakan air yang cukup bagi kebutuhan tanaman, kondisi tanah ini pun juga miskin unsur hara sehingga dibutuhkan dosis pemupukan yang lebih banyak, karakter lainnya yakni tanah yang berbatu sehingga sangat sulit untuk diolah secara mekanis.

Dalam penanganan masalah ini maka diperlukan upaya yang tepat yakni dengan menggunakan teknik irigasi sesuai sehingga permasalahan tersebut dapat diatasi sehingga lahan kering tersebut dapat termanfaatkan

Salah satu sistem irigasi yang baik untuk dikembangkan ke arah otomatisasi adalah irigasi tetes, yaitu irigasi bertekanan rendah dengan efisiensi penggunaan air irigasi paling tinggi dibandingkan dengan sistem irigasi yang 
lainnya (Udiana et al., 2014). Menurut Pasaribu et al. (2013) Irigasi tetes hanya memberikan air pada perakaran tanaman. Evaporasi dari tanah dapat lebih rendah karena hanya sebagian dari luasan permukaan tanah yang basah. Manfaat yang dapat diperoleh dari penerapan sistem irigasi tetes diantaranya adalah bakteri, hama dan penyakit lain yang tergantung pada lingkungan lembab dapat dikurangi, karena bagian tanaman yang ada di atas tanah umumnya kering (Ridwan, 2013). Sistem irigasi tetes secara konvensional telah banyak dilakukan sebelumnya (Yanto et al., 2014), namun tidak dilengkapi dengan sistem kendali otomatis untuk mengatur jadwal pemberian irigasinya sehingga tingkat efektifitasnya rendah. Penambahan sistem kendali otomatis dengan menggunakan mikrokontroler diharapkan mampu meningkatkan kinerja sistem karena pemberian air sesuai dengan kebutuhan tanaman (Marpaung, 2013).

\section{Sistem irigasi tetes untuk tanaman}

Dalam mengatasi pertumbuhan pada saat musim kemarau, diperlukan irigasi yang baik untuk memenuhi kebutuhan air bagai kehidupan tanaman. Sumber air irigasi yang lebih sering dipergunakan biasanya menggunakan air dari saluran, ataupun dari sumur pompa. Saat ini penggunaan irigasi tetes di kalangan petani masih sangat minim, ini dikarenakan biaya instalasinya yang mahal, namun hal ini dapat diatasi dengan mengganti komponen sistem irigasi yang mahal menggunakan komponen yang sederhana tetapi dengan fungsi yang sama sehingga petani tetap bisa menggunakan sistem irigasi tetes dan mendapatkan keuntungan yang lebih besar
(Pasaribu et al., 2013). Inovasi teknologi jaringan irigasi tetes di tingkat petani perlu dilakukan sehingga keuntungan yang didapatkan dalam irigasi tetes (penggunaan air efisien dan mempermudah pemberian air) dapat diraih dengan biaya investasi yang terjangkau Setiapermas \& Zamawi (2015).

Dalam pengoptimalan penggunaan air yang baik maka, pemberian air harus disesuaikan dengan kebutuhan air tanaman, agar irigasi ini bisa menjadi lebih efisien. karena jika tanam menerima banyak air juga akan memberikan dampak yang buruk bagi tanaman, Menurut (Haryati,2014), Jumlah air yang diberikan melebihi dari kemampuan tanah untuk menyimpan air dapat mengakibatkan air bergerak sepanjang permukaan (aliran permukaan) atau bergerak ke lapisan bawah tanah (perkolasi)

Dalam merancang irigasi tetes, jumlah pemberian tetesan emitter, waktu dan debit air dapat ditentukan melalui persamaan $\mathrm{EDR}=\mathrm{q} /$ s x 1 Dimana laju tetesan emitter (EDR) dinyatakan dalam mm/jam, debit emitter (q) dinyatakan dalam $\mathrm{m}^{3} / \mathrm{jam}$ jarang antar lubang emitter (s) dan jarak lateral emiter (l) dinyatakan dalam $\mathrm{m}$. Waktu pengoperasian irigasi tetes dapat dinyatakan sebagai hasil perbandingan kebutuhan air tanaman terhadap laju tetesan emitter (EDR), sedangkan debit air pada irigasi tetes diperoleh dari hasil perkalian debit emitter (q) dan jumlah lubang emitter terhadap per satuan waktu (jam) (Udiana et al., 2014). 


\section{Pengaruh beberapa tekstur tanah terhadap}

efisiensi penggunaan air dengan

\section{menggunakan metode Irigasi Tetes}

Tekstur tanah merupakan suatu faktor yang penting karena sifatnya yang dapat mempengaruhi pertumbuhan tanaman, serta tidak langsung dapat memperbaiki peredaran air yang ada di dalam tanah, udara, maupun panas. Tanah yang memiliki struktur baik juga akan membantu pertumbuhan pada tanaman secara optimal, sedangkan sifat tanah yang bersifat jelek akan menghambah pertumbuhan tanaman ini sendiri. Suatu struktur tanah dapat dikatakan baik jika di dalamnya terdapat penyebaran ruang serta pori-pori yang baik

Tekstur tanah merupakan suatu sifat fisik yang penting karena dapat mempengaruhi pertumbuhan tanaman serta secara tidak langsung dapat memperbaiki peredaran air, udara dan panas, aktivitas jasad hidup tanah, tersedianya unsur hara bagi tanaman, perombakan bahan organik, dan mudah tidaknya akar dapat menembus tanah lebih dalam. Tanah yang berstruktur baik akan membantu berfungsinya faktor-faktor pertumbuhan tanaman secara optimal, sedangkan tanah yang berstruktur kurang baik akan menyebabkan terhambatnya pertumbuhan tanaman. Suatu struktur pada tanah yang bisa dikatakan baik apabila di dalam tanah tersebut terdapat penyebaran ruang dan pori-pori yang baik. Struktur tanah juga sebaiknya tidak mudah hancur.
Menurut Hanafiah (2013), fungsi utama tanah sebagai media tumbuh adalah sebagai tempat akar mencari ruang untuk berpenetrasi (menelusup), baik secara lateral atauhorisontal maupun secara vertikal. Kemudahan tanah untuk dipenetrasi ini tergantung pada ruang pori-pori yang terbetuk diantara partikelpartikel tanah (tekstur dan struktur), sedangkan stabilitas ukuran ruang ini tergantung pada konsistensi tanah terhadap pengaruh tekanan.

Simangunsong et al. (2013) menyatakan beragaman tanah, metode irigasi, lama pengaliran, tekstur tanah, permeabilitas, dan kedalaman tanah mempengaruhi kehilangan air dan efisiensi yang rendah. Efisiensi penyimpanan tertinggi pada fase tengah terdapat pada tekstur liat dengan rata-rata $89,18 \%$ dan terendah terdapat pada tekstur lempung rata-rata $56,61 \%$, karena tekstur liat memiliki porositas yang lebih besar sehingga air yang tersimpan di dalam tanah lebih besar.

Menurut penelitian yang dilakukan Mustawa et al. (2017) menyatakan tekstur liat memiliki tingkat efisiensi penyimpanan dan pemakaian paling tinggi dibandingkan dengan tekstur lempung dan lempung liat berpasir. Semakin tinggi pemberian air irigasi yang diberikan kepada tanaman, maka semakin rendah efisiensi pemakaian dan semakin tinggi efisiensi penyimpanan pada masing-masing tekstur tanah dan begitu juga sebaliknya. 
Tabel 1. Efisiensi irigasi tetes pada fase akhir tekstur lempung, liat dan lempung liat berpasir (Mustawa, 2017)

\begin{tabular}{ccccccc}
\hline \multirow{2}{*}{ Emitter ke- } & \multicolumn{5}{c}{ Tekstur Tanah } \\
\cline { 2 - 7 } & \multicolumn{2}{c}{ Lempung } & \multicolumn{2}{c}{ Liat } & \multicolumn{2}{c}{ Lempung liat berpasir } \\
\cline { 2 - 7 } & Ea $(\%)$ & Es $(\%)$ & Ea (\%) & Es $(\%)$ & Ea (\%) & Es (\%) \\
\hline 1 & 98.63 & 22.81 & 100 & 64.54 & 100 & 47.89 \\
2 & 99.41 & 24.17 & 100 & 66.36 & 99.41 & 49.85 \\
3 & 100 & 19.27 & 100 & 66.12 & 100 & 48.94 \\
4 & 98.83 & 26.06 & 100 & 71.43 & 99.02 & 49.80 \\
5 & 99.02 & 27.54 & 100 & 63.92 & 100 & 49.69 \\
6 & 100 & 23.30 & 100 & 64.21 & 99.64 & 46.72 \\
7 & 98.43 & 21.15 & 100 & 72.90 & 100 & 46.90 \\
8 & 99.61 & 21.37 & 100 & 69.96 & 100 & 51.41 \\
9 & 98.82 & 24.67 & 100 & 67.26 & 100 & 48.84 \\
10 & 99.61 & 22.66 & 100 & 68.06 & 100 & 48.20 \\
\hline Rataan & 99.24 & 23.3 & 100 & 67.48 & 99.81 & 48.82 \\
\hline
\end{tabular}

Dari hasil tersebut maka dapat disimpulkan bahwa pada tekstur liat memiliki tingkat efisiensi terhadap penyimpanan dan juga pemakaian yang paling tinggi dibandingkan dengan tanah dengan tekstur lempung mapun liat dan berpasir.

\section{Manfaat penerapan irigasi tetes terhadap efisiensi air}

Kekurangan air menjadikan salah satu masalah utama di lahan kering dimana proses peertanian tidak bisa dilakukan tanpa ketersediaanya air irigasi, efisien dari air irigasi penting dilakukan untuk pembangunan berkelanjutan dan upaya pengelolaan sumber daya air di wilayah tersebut.

Pemanfaatan irigasi tetes di bidang pertanian memiliki banyak manfaat antara lain sebagai pengehematan air dikarenakan dalam proses pemberian air diberikan ketanaman sesuai dengan kebutuhan tanam itu sendiri, mengehemat waktu, karena penyiraman dilakukan dengan cara otomatis, ada contoh alat yang menyerupai timer yang bisa mengatur proses pengairan air sehingga air dapat mengalir di waktu - waktu tertentu,

Dengan adanya teknik pengairan dengan menggunakan irigasi tetes ini nantinya diharapkan bisa membantu memenuhi kebutuhan air tanaman pada musim kemarau dengan cara menjaga penggunaan air secara efisien sehingga nanti juga akan meningkatkan pemanfaatan unsur hara tanah, mengurangi tekanan air terhadap tanah dan mempercepat adaptasi dari bibit, dan juga akan meningkatkan keberhasilan tumbuh tanaman, Simonne et al. (2010) juga mengatakan bahwa Efisiensi penggunaan air dengan sistem irigasi tetes dapat mencapai 80 - 95\%

Penerapan irigasi tetes sangat efisien dalam penggunaan air, dikarenakan air dialirkan ke tanaman tetes demi tetes sehingga dapat diatur sesuai dengan kebutuhan tanaman, 
kegiatan budidayapun tidak lagi tergantung pada musim, lahan dapat ditanami sepanjang tahun tidak bergantung pada cuaca, sehingga indek penanaman pun juga akan meningkat. Namun demikian teknologi irigasi tetes merupakan teknologi yang melibatkan proses manajemen air, sehingga ketersediaan air juga tetap harus dibutuhkan, sehingga penerapan teknologi ini juga perlu dibarengi dengan ketersediaan sumber air yang memadai

Menurut Rizky (2018), teknologi irigasi tetes mampu mengelola pemberian air pada zona perakaran tanaman secara berkelanjutan sehingga dapat meningkatkan produktifitas lahan dan kegiatan budidaya dapat berlangsung sepanjang waktu. Penerapan sistem irigasi tetes dapat meningkatkan efisiensi penggunaan air pada tanaman karena mampu bekerja berdasarkan kondisi aktual lahan pertanian melalui level kelengasan tanah

\section{KESIMPULAN DAN SARAN}

Irigasi tetes bisa menjadi suatu pilihan tepat untuk mengatasi masalah kekeringan terutama pada pertumbuhan tanaman buah dan sayuran di saat musim kemarau panjang, karena kemarau panjang menyebabkan lahan memiliki sedikit persediaan air. Metode irigasi tetes pun juga sangat membantu dalam memperlambat proses penguapan air pada saat musim kemarau

Penggunaan tanah dengan tekstur liat sangat tepat dalam penerapan metode irigasi tetes ini dikarenakan memiliki tingkat penyimpanan dan pemakaian air yang sangat tinggi sehingga dapat meningkatkan efisiensi dalam penggunaan air.

\section{DAFTAR PUSTAKA}

Afriyana, D., A. Tusi, \& Oktafri. (2011). Analisis Pola Pembasahan Tanah dengan Sistem Irigasi Tetes Bertekanan Rendah. Jurnal Teknik Pertanian Lampung, 1 (1): 43-50.

Arsyad, S. (2010). Konservasi Tanah dan Air. Penerbit IPB. Bandung

Ekaputra, E.G., Yanti, D., Saputra, D., \& Irsyad, F. (2016). Rancang Bangun Sistem Irigasi Tetes untuk Budidaya Cabai (Capsicum annum L.) dalam Green House di Nagaro Biaro, Kecamatan Ampek Angkek, Kabupaten Agam, Sumatera Barat. Jurnal Irigasi, 11(2):103-112

Hadiutomo, K. (2012). Mekanisasi Pertanian. IPB Press. Bogor.

Hanafiah, K. A. (2013). Dasar-Dasar Ilmu Tanah. Rajawali Press, Jakarta.

Haryati, U., Abdurachman, A., \& Subagyono, K. 2011. Efisiensi Penggunaan Air Berbagai Teknik Irigasi untuk Pertanaman Cabai di Lahan Kering pada Typic Kanhapludult Lampung. Prosiding Seminar Nasional Sumberdaya Lahan Pertanian. Bogor, 30 November-1 Desember 2010. Buku III. Pengelolaan Air, Iklim dan Rawa. Balai Besar Penelitian dan Pengembangan Sumberdaya Lahan Pertanian. Badan Litbang Pertanian. Kementrian Pertanian. 23 - 46

Haryati, U. (2014). Teknologi Irigasi Suplemen untuk Adaptasi Perubahan Iklim pada Pertanian Lahan Kering. Jurnal Sumberdaya Lahan, 8 (1) : 43-57.

Kurniati, E., Bambang, S., \& Afrilia, T. (2014). Desain Jaringan Irigasi (Springkler Irrigation) pada Tanaman Anggrek. Jurnal Teknologi Pertanian, 8(1) 35-45

Marpaung, R. (2013). Estimasi Nilai Ekonomi Air dan Eksternalitas Lingkungan pada Penerapan Irigasi Tetes dan Alur di lahan Kering Desa Pejarakan Bali. Jurnal Sosial Ekonomi Pekerjaan Umum.

Marpaung, R. (2013). Estimasi Nilai Ekonomi Air dan Eksternalitas Lingkungan pada Penerapan Irigasi Tetes dan Alur di Lahan Kering Desa Pejarakan Bali. Jurnal Sosial Ekonomi Pekerjaan Umum, 5(1):65-75. 
Mustawa, M., Abdullah1, S. H., \& Putra, G. M. D. (2017). Analisis Efisiensi Irigasi Tetes Pada Berbagai Tekstur Tanah untuk Tanaman Sawi (Brassica juncea). Jurnal Ilmiah Rekayasa Pertanian dan Biosistem

Olayide, O.E., Tetteh, I.K., \& Popoola, L. (2016). Differential Impacts of Rainfall and Irrigation on Agricultural Production in Nigeria: Any lessons for Climate-Smart Agriculture? Journal of Agricultural Water Management, 178: 30-36.

Pasaribu, I.S., Sumono, Daulay, S.B., \& Susanto, E. (2013). Analisis Efisiensi Irigasi Tetes dan Kebutuhan Air Tanaman Semangka (Citrullus vulgaris S.) pada Tanah Ultisol. Jurnal Rekayasa Pangan dan Pertanian, 2 (1): 90-95

Prastowo. (2010). Teknologi Irigasi Tetes. Bogor: Jurusan Teknik Pertanian, Fakultas Teknologi Pertanian, Institut Pertanian Bogor.

Rizky, T., (2018). Amin Rejo. Teknologi Irigasi Tetes dalam Mengoptimalkan Efisiensi Penggunaan Air di Lahan Pertanian. Universitas Sriwijaya. Palembang

Rana, M. \& Rahim, A. (2014). Manuring and Irrigation Effect on Growth, Flowering, and Fruiting of Dragon Fruit (Hylocereus undatus Haw) In Bangladesh. IJCBS RESEARCH PAPER 1(6): 28-32

Racmad, N. (2009). Irigasi dan Tata Guna Lahan. PT Gramedia. Jakarta

Ridwan, D. (2013). Model Jaringan Irigasi Tetes Berbasis Bahan lokal untuk Pertanian Lahan Sempit. Jurnal Irigasi

Setiapermas, M.N. \& Zamawi. (2015). Pemanfaatan Jaringan Irigasi Tetes di dalam Budidaya Tanaman Hortikultura. Dalam I. Djatnika, M. J. . Syah, D. Widiastoety, M. P. Yufdy, S. Prabawati, S. Pratikno, \& O. Luftiyah (Ed.), Inovasi Hortikultura Pengungkit Peningkatan Pendapatan Rakyat. Jakarta: IAAR Press.

Simangunsong, F. T., Sumono, Rohanah, A. \& Susanto, E. (2013). Analisis Efisiensi Irigasi Tetes dan Kebutuhan Air Tanaman Sawi (Brassica juncea) pada Tanah Inceptisol. Jurnal Rekayasa Pangan dan Pertanian

Simonne, E.H., Dukes, M.D., \& Zotarelli, L. (2010). Principles and Practices of
Irrigation Management for Vegetables. Chapter 3. IFAS Extension. Florida.

Udiana. (2014). Perencanaan Sistem Irigasi Tetes (Drip Irrigation) di Desa Besmarak, Kabupaten Kupang. Jurnal Teknik Sipil

Umar, S. \& Prabowo, A. (2011) Penggunaan Mesin Fertigasi Tipe APH-03 pada Tanaman Cabai di Lahan Lebak. Agrista.

Yanto, H., Tusi, A., \& Triyono, S. (2014). Aplikasi Sistem Irigasi Tetes pada Tanaman Kembang Kol (Brassica Oleracea Var. Botrytis L. Subvar. Cauliflora DC) dalam Green House. Jurnal Teknik Pertanian Lampung. 